\title{
DIET AND REPRODUCTION OF THE GOLIATH GROUPER, EPINEPHELUS ITAJARA (ACTINOPTERYGII: PERCIFORMES: SERRANIDAE), IN EASTERN BRAZIL
}

\author{
Matheus O. FREITAS 1, 2,3*, Vinícius ABILHOA ${ }^{2,3}$, Vinicius J. GIGLIO ${ }^{4}$, \\ Maurício HOSTIM-SILVA ${ }^{1,5}$, Rodrigo L. de MOURA ${ }^{6}$, Ronaldo B. FRANCINI-FILHO ${ }^{7}$, \\ and Carolina V. MINTE-VERA ${ }^{8,9}$ \\ ${ }^{1}$ Instituto Meros do Brasil, Brazil \\ ${ }^{2}$ Grupo de Pesquisa em Ictiofauna - GPIC, Museu de História Natural Capão da Imbuia, Curitiba, PR, Brazil \\ ${ }^{3}$ Programa de Pós-Graduação em Zoologia, Universidade Federal do Paraná, Curitiba, PR, Brazil \\ ${ }^{4}$ Programa de Pós-Graduação em Ecologia, Universidade Federal do Rio de Janeiro, Rio de Janeiro, RJ, Brazil \\ ${ }^{5}$ Universidade Federal do Espirito Santo - UFES-DCAB - CEUNES, São Mateus, ES, Brazil \\ ${ }^{6}$ Instituto de Biologia, Depto de Biologia Marinha, Universidade Federal do Rio de Janeiro. \\ Rio de Janeiro, RJ, Brazil \\ ${ }^{7}$ Universidade Federal da Paraiba, Centro de Ciências Aplicadas e Educação, Campus IV - Litoral Norte, \\ Rio Tinto, PB, Brazil \\ ${ }^{8}$ Núcleo de Pesquisas em Limnologia Ictiologia e Aquicultura, Universidade Estadual de Maringá, \\ Maringá, PR, Brazil \\ ${ }^{9}$ Inter-American Tropical Tuna Commission, La Jolla, CA, USA (present address)
}

Freitas M.O., Abilhoa V., Giglio V.J., Hostim-Silva M., Moura R.L., Francini-Filho R.B., Minte-Vera C.V. 2015. Diet and reproduction of the goliath grouper, Epinephelus itajara (Actinopterygii: Perciformes: Serranidae), in eastern Brazil. Acta Ichthyol. Piscat. 45 (1): 1-11.

Background. The goliath grouper, Epinephelus itajara (Lichtenstein, 1822), is the largest Atlantic grouper. It has been the first marine fish subjected to a fishing moratorium in Brazil (since 2002). The aim of this study was to investigate basic biological aspects, particularly the diet and reproduction of this endangered species. We believe that our results, together with information already available in the literature, may be a foundation for new management and conservation strategies for this grouper in Brazil.

Materials and methods. Specimens were obtained from an artisanal fish landings collaborative monitoring program in the cities of Caravelas and Alcobaça, Abrolhos Bank, eastern Brazil. Because of the fishing moratorium, we relied on sporadic incidental captures from fishermen or donation from the law enforcement agencies. Diet and reproduction of the goliath grouper was evaluated based on 34 specimens obtained between May 2005 and September 2010.

Results. Body size of 32 females ranged from 27.4 to $150.0 \mathrm{~cm}$ total length (TL) (mean $87.4 \pm$ SD 34.8), while size of 2 males were 97.0 and $115.0 \mathrm{~cm}$ TL. Of these, 16 specimens (47\%) were juveniles. Sex ratio was estimated as $1: 16$ (males to females). Two developing females were recorded, one obtained in February 2006 and another in January 2007. The length of first maturation $\left(L_{50}\right)$ for females was estimated at $105.64 \mathrm{~cm}$ and the length where $100 \%$ of individuals are mature $\left(L_{100}\right)$ at $126.0 \mathrm{~cm}$ TL. A total of 34 stomachs were analyzed, six of them were empty. Teleosts and decapods dominated the diet. The major food items of mangrove-associated fish were decapods Callinectes sp., while the coral reef-associated fish ingested mainly the boxfish Acanthostracion sp. The most important item for juveniles was Callinectes sp., while Acanthostracion sp. was the most important item for adults.

Conclusion. We suggest that the goliath grouper moratorium in Brazil should be maintained for a relatively long time frame-more than four decades.

Keywords: fish conservation; Abrolhos Bank; threatened fishes, fisheries management, ontogenetic variations, Epinephelinae

\footnotetext{
${ }^{*}$ Correspondence: Dr. Matheus Oliveira Freitas, GPIC, Museu de História Natural Capão da Imbuia, Rua Prof. Benedito Conceição, N. 407. CEP: 82810-080, Curitiba, PR, Brazil, phone: +55 41 3267-0819, e-mail: (MOF) serranidae@gmail.com, (VA)vabilhoa@uol.com.br, (VJG) vj.giglio@gmail.com, (MHS) mhostim@gmail.com, (RLM)moura@biologia.ufrj.br, (RBFF) rbfrancinifilho@gmail.com, (CVMV) cmintevera@gmail.com.
} 


\section{INTRODUCTION}

The goliath grouper, Epinephelus itajara (Lichtenstein, 1822), is the largest Atlantic grouper, exceeding 2 meters of total length (TL), and $>400 \mathrm{~kg}$ of weight (Bullock et al. 1992). It inhabits tropical and subtropical coastal and estuarine areas on both sides of the Atlantic (Heemstra and Randall 1993) from Florida to southern Brazil, including the Gulf of Mexico, as well as along the west coast of Africa (Bullock et al. 1992, Heemstra and Randall 1993). The goliath grouper is a mangrove-dependent reef fish with the post-larval and juvenile phases thought to recruit to estuaries (FriasTorres 2006, Frias-Torres and Luo 2009). In southern Brazil, however, juveniles $(<100 \mathrm{~cm})$ were recorded in open waters (Félix-Hackradt and Hackradt 2008). In the Northern Hemisphere, juveniles generally show high site fidelity, moving little within their home range and rapidly returning to their original habitat after handling (Eklund and Schull 2001, Frias-Torres et al. 2007). Goliath grouper is an opportunistic ambush predator and feeds at a relatively low trophic level (Koenig and Coleman 2009). The diet includes slow-moving fishes, invertebrates (particularly lobsters and crabs), and even sea turtles (Randall 1967, Bullock and Smith 1991).

The goliath grouper is extremely vulnerable to overfishing (principally spearfishing and long-lines), mainly due to critical life history traits such as slow growth, late gonadal maturity, long life span, strong site fidelity, and formation of seasonal spawning aggregations (Bullock et al. 1992, Sadovy and Eklund 1999, Morris et al. 2000, Eklund and Schull 2001). The International Union for Conservation of Nature (IUCN) lists it as a critically endangered species (Craig 2011). In Brazil, it has been fully protected by the federal law since September 2002 (Hostim-Silva et al. 2005) and the main demand to support new management measures would be to obtain information on the population status and species recovery. This moratorium was renewed twice in 2007 and 2012 for another three years*. In the South Atlantic there has almost been no studies on the basic life history traits of this fish. In Brazil, available information is fragmented and insufficient for a comprehensive evaluation of the population status. Available data comes from studies on the local ecological knowledge, from artisanal fishermen, spatio-temporal characteristics of aggregations (Ferreira and Maida 1995, Gerhardinger et al. 2006, 2009, ReussStrenzel and Assunção 2008), monitoring of population size (Félix-Hackradt and Hackradt 2008), genetic characterization of populations, and cryptic genetic divergence (Silva-Oliveira et al. 2008, 2013, Craig et al. 2009). No data, however, is available on its growth, maturity, fecundity, and diet.

Combined with commercial and recreational fisheries data, the biological information collected from fisheries can contribute to regular assessments of the status of fish stocks, helping the evaluation of fisheries management strategies (Pilling et al. 2008). Length and age at first mat- uration, maximum size, and reproductive patterns, for example, are essential for fishery management of larger groupers and snappers (Freitas et al. 2011b, 2014), as well as the information on predator/prey abundance and consumption rates of predators, which may be used to assess the magnitude of trophic fluxes (Heithaus et al. 2010).

Herein we investigate the diet and reproduction, of Epinephelus itajara specimens obtained from an artisanal fish landings collaborative monitoring program in the Abrolhos Bank, eastern Brazil. The region features the richest coralline complex in the South Atlantic known for its biodiversity and also for serious threats to its integrity and existence (Moura et al. 2013). The emphasis was placed on the assessment of ontogenetic and habitat shifts in diet, as such information may be relevant for future attempts to model trophic pathways and assess the possible ecosystem implications of E. itajara removal (Pauly et al. 1998, Farmer and Wilson 2011). We believe that our results, together with information already available in the literature, may be a foundation for new management and conservation strategies for the goliath grouper in Brazil.

\section{MATERIAL AND METHODS}

Study area. This study was carried out in the Abrolhos Bank, Bahia State, eastern Brazil, which encompasses a wide portion $\left(42000 \mathrm{~km}^{2}\right)$ of the continental shelf, with depth rarely exceeding $30 \mathrm{~m}$ and a shelf edge at about $70 \mathrm{~m}$ depth $\left(16^{\circ} 40^{\prime}-19^{\circ} 40^{\prime} \mathrm{S}, 39^{\circ} 10^{\prime}-37^{\circ} 20^{\prime} \mathrm{W}\right)$. The region comprises the largest and richest coral reefs in the South Atlantic, as well as an extensive mosaic of algal bottoms, mangrove forests, beaches, and vegetated sandbanks (Leão and Kikuchi 2005, Moura et al. 2013). Four marine protected areas (MPA) occur in the region, one of them with large mangroves - the Cassurubá Extractive Reserve (CER; multiple use; $1006 \mathrm{~km}^{2}$ ), in which the fishing activities are either recreational or for subsistence (Moura et al. 2011). The other three MPAs encompass important reef formations: the Abrolhos Marine National Park (no fishing allowed; $913 \mathrm{~km}^{2}$ ), the Corumbau Marine Extractive Reserve (multiple use; $895 \mathrm{~km}^{2}$ ), and the Environmental Protected Area Ponta da Baleia/Abrolhos $\left(3460 \mathrm{~km}^{2}\right)$, which in fact is a reserve only theoretically due to the lack of regulations (Francini-Filho and Moura 2008a, Francini-Filho et al. 2013). About 290 species of fishes are recorded in the region (Dutra et al. 2005, Previero et al. 2013). Most reef structures display a characteristic form of mushroom-shaped pinnacles, which attain 5 to $25 \mathrm{~m}$ in height and 20 to $300 \mathrm{~m}$ across their tops (Francini-Filho and Moura 2008b). Brazilian reefs are a conservation priority in the Atlantic Ocean due to high endemism levels (about 25\% in fish and $30 \%$ in scleractinian corals) that are concentrated in only $5 \%$ of West Atlantic reefs (Francini-Filho et al. 2013). The rich biodiversity of the Abrolhos Bank is threatened by overfishing, pollution, dredging, sedimentation from coastal deforestation, and large-scale oil-gas exploration projects (Leão and Kikuchi 2005, Moura et al. 2013).

\footnotetext{
${ }^{*}$ In December 2014, the Brazilian government published a new endangered species list according IUCN criteria. Goliath grouper was categorized as critically endangered, because has not shown signs of population recovery.
} 
Sampling and analytical procedures. Specimens of Epinephelus itajara were obtained from an artisanal fish landing monitoring program of commercially important reef fishes (see Freitas et al. 2011b) that focused on fish caught using hook and line, longline, spearfishing, and gillnets in the main fish markets in the cities of Caravelas and Alcobaça (Fig. 1). All the mangrove individuals were collected in the CER. Sampling was performed in collaboration with local fishermen opportunistically between June 2005 and September 2010. Because of the moratorium on fishing of the species, biological studies rely on donation by fishermen after sporadic incidental captures and/or donation by the law enforcement agencies after confiscations, (permits \# 038/2004 DIFAP-IBAMA, 042/2006 DIFAP-IBAMA and SISBIO 15080-5).

In the laboratory, the total length (TL) of individuals was measured to the nearest $1 \mathrm{~mm}$ and the total weight (TW) was determined to the nearest $10 \mathrm{~g}$. Stomach and gonads were removed and immediately fixed in $10 \%$ formalin solution for $24 \mathrm{~h}$ and subsequently transferred and stored in $70 \%$ ethanol. Stomach contents were examined in laboratory using a stereomicroscope. Prey individuals were identified to the highest possible taxonomic level according to specialized literature (Matsuura 2001) and consultation with experts. Parameters such as percentage Frequency of occurrence $(F)$ (i.e., percentage of stomachs where the food item was present), gravimetric abundance a food item $\left(W_{\mathrm{A}}\right)$ (i.e., percentage of the weight of a food item in relation to the weight of total food), as well as the numerical abundance of a food item $(N)$ (i.e., percentage of the number of food item $i$ in relation to the total number of all food items) were determined (Hyslop 1980, Bowen 1996). These variables were used to calculate the Index of Relative Importance (IRI) (see Pinkas et al. 1971), according to the equation

$$
\mathrm{IRI}=\left(N+W_{\mathrm{A}}\right) \times F
$$

The IRI establishes the order of importance of food items in the diet. IRI values were standardized to percentages following Cortés (1999).

Variations on diet according to the factors habitat (coral reefs or mangroves) and ontogeny (juveniles: $<100 \mathrm{~cm} \mathrm{TL}$, or adults: $>100 \mathrm{~cm} \mathrm{TL}$ ) were examined using multivariate analyses considering all individuals with no empty stomachs $(n=28)$. Size classes were established according to our results on $L_{50}$ for Epinephelus itajara in Abrolhos Bank (see results). A two-way permutational multivariate analysis of variance (PERMANOVA) examined the effects of the factors habitat (fixed, two levels) and ontogeny (fixed, two levels) on the standardized and transformed $(\log x+1)$ weight contribution of items. The Bray-Curtis dissimilarity was used in all tests, using unrestricted permutation of raw data with 999 random permutations. Similarity of percent contribution (SIMPER) analysis was employed to examine the prey categories most responsible for the between-factors separation (Clarke and Gorley 2001). Non-metric multidimensional scaling (NMDS) was employed to visually assess dispersion of individuals. Vectors superimposed to the NMDS diagram

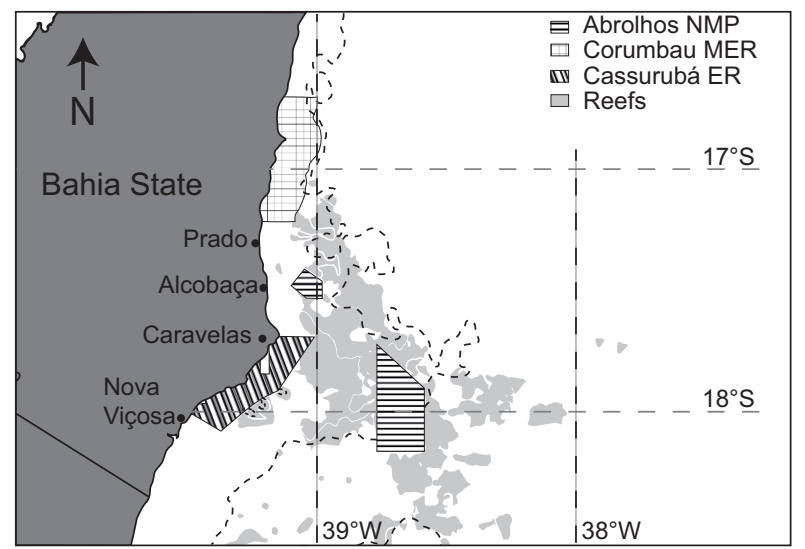

Fig. 1. Map of the Abrolhos Bank, eastern Brazil

were created by using the Spearman's correlation on the proportionate contributions of food items. The final solution represents the set of relations between samples and food items in a two-dimensional, with determination of the stress level of the representation (Clarke and Gorley 2001). All analyses were performed using the PRIMER-E 6.0 software (Plymouth Marine Laboratory, Plymouth, England).

Gonad weight (GW) was determined to the nearest $0.01 \mathrm{~g}$. Sex and maturity were macroscopically determined from gonad size, consistency, colour, vascularization, presence of lateral sperm sinuses, ovarian cavity, ovarian lamellae, and identifiable oocytes (Colin et al. 2003). After macroscopic classification, gonads were dehydrated with increasing alcohol concentration series, cleared in xylene, and then embedded in histological paraffin. Histological sections of 4-6 $\mu \mathrm{m}$ were stained in Harris haematoxylin and eosin. Five developmental phases were considered following Brown-Peterson et al. (2011): immature (IM), developing (DV), spawning capable (SC), regressing (RG), and regenerating (RT). The IM phase corresponds to a fish that has never spawned, characterized histologically in females by the presence of oogonia and primary growth oocytes through the perinuclear stage, as well as little space among oocytes in the lamellae and ovarian wall generally thin (Brown-Peterson et al. 2011). In DV females, the ovary is beginning to develop, but not ready to spawn. The SC fish are developmentally and physiologically able to spawn; the RG represents the cessation of spawning and the RT phase corresponds to a sexually mature, but reproductively inactive individual.

Sex ratio was estimated using Bayesian method using the total numbers of females $(f)$ and the number of females plus males $(n)$. We used the conjugate beta-binomial model to estimate the proportion of females with uninformative beta $(1,1)$ as a prior distribution and beta $(f+1, n-f+1)$ as posterior distribution (Gelman et al. 2004). The minimum size at maturity $\left(L_{\mathrm{min}}\right)$ was recorded for females. The TL at which $50 \%$ of females were mature $\left(L_{50}\right)$ (King 2007) was estimated using Bayesian methods (Kinas and Andrade 2010). The following logistic regression model was used:

$$
\mathrm{PMF}=1 \times(1+\exp (\mathrm{a}+\beta \times L))^{-1}
$$

where PMF is the proportion of mature females in length 
class $L$, a is a parameter, and $L_{50}=-\mathrm{a} \times \beta^{-1}$. For the $L_{50}$ analysis, developing, spawning capable, actively spawning, regressing, and regenerating individuals were considered as sexually mature (adults). The model was implemented using the Automatic Differentiation Model Builder (ADMB) software (Fournier et al. 2012) and uninformative priors. Samples from the posterior distributions of the parameters were obtained using the Markov Chain Monte Carlo algorithm (Gelman et al. 2004) with a 10 million chain and samples saved once every 10000 interactions.

\section{RESULTS}

General biological parameters and reproduction. A total of 34 specimens (32 females and 2 males) of Epinephelus itajara were analyzed (Fig. 2), and from these $16(47 \%)$ specimens were juveniles. Body size of females (94.1\% of sampled animals) ranged from 27.4 to $150 \mathrm{~cm}$ TL (mean 87.4 \pm SD 34.8), while the size values of males (5.9\%) were 97.0 and $115.0 \mathrm{~cm}$ TL. The length-weight relation was estimated at $\mathrm{TW}=$ $0.0004 \mathrm{TL}^{3.8127}\left(r^{2}=0.7004, n=34\right)$. Sex ratio was $1: 16$ males to females, with the median of the posterior distribution of the proportion of females equal to $0.924(90 \%$ credibility interval $=0.831-0.976)($ Fig. 3$)$.

Analyses of gonadal histological sections confirmed the predominance of immature females. Only two developing females were recorded (Fig. 4), one obtained on 2 February 2006 and another on 28 January 2007. The beginning of the reproductive period is indicated by the presence of the early developing sub-phase, in which only the primary growth and cortical alveolar are present. Thus, the spawning season of Epinephelus itajara in the Abrolhos Bank may occur during austral summer (January to March). Nine RT females were registered between April and October. The two males were classified as RT and caught in January and April 2007. We did not record any histological evidence of hermaphrodite individuals. The $L_{50}$ for females was estimated at $105.5 \mathrm{~cm}$ (mean of the posterior distribution, 90\% credibility interval $=992.57-1116.72$, Figs. 5 and 6) and $L_{100}$ at $126.0 \mathrm{~cm}$ TL.

Diet. A total of 34 stomachs were analyzed, six of them were empty (17.4\%). Among the 12 items consumed by Epinephelus itajara, the most important were fishes (IRI $=46.31 \%$ ), fish remains (IRI $=28.14 \%)$, the boxfish, Acanthostracion sp., (IRI = 12.32\%), and decapods (IRI = $52.77 \%$ ), with Callinectes sp. corresponding to IRI = 42.59\%. Teleosts and decapods dominated the diet based on all dietary metrics. Among identifiable prey items, the blue crab, Callinectes ornatus $(F=25.0 \% ; n=1)$, and the blackpoint sculling crab, Cronius ruber $(F=7.14 \% ; n=5)$, were the most important prey based on number and frequency of occurrence (Table 1). The major food items of mangrove-associated fish were Callinectes sp. (IRI = $87.97 \%$ ) and fish remains (IRI $=10.93 \%$ ), while coral reefassociated fish ingested mainly Acanthostracion sp. $(\mathrm{IRI}=37.92 \%)$, fish remains $(\mathrm{IRI}=29.10 \%)$, and
Brachyura (IRI $=5.91 \%$ ). The analysis performed for different size classes showed that Callinectes sp. (IRI = $66.51 \%$ ) and fish remains (IRI $=27.40 \%$ ) were the most important items for juveniles. Most important items for adults were Acanthostracion sp. (IRI $=70.79 \%$ ), followed by yellowtail snapper, Ocyurus chysurus (Bloch, 1791) $(\mathrm{IRI}=8.57 \%)$ and Haemulon spp. (IRI $=6.58 \%)$.

The PERMANOVA analysis revealed differences in diet between juveniles and adults (Pseudo- $F=2.44$ and $P=0.009)$ and also considering the interaction between the factors size and habitat (Pseudo- $F=2.03$ and $P=0.034$ ) (Table 2). However, the diet between habitat categories was marginally significant (Pseudo- $F=1.85$ and $P=0.052$ ).

Pairwise tests found that the diet of juveniles vary significantly between habitats (Table 3 ). In spite of the dietary

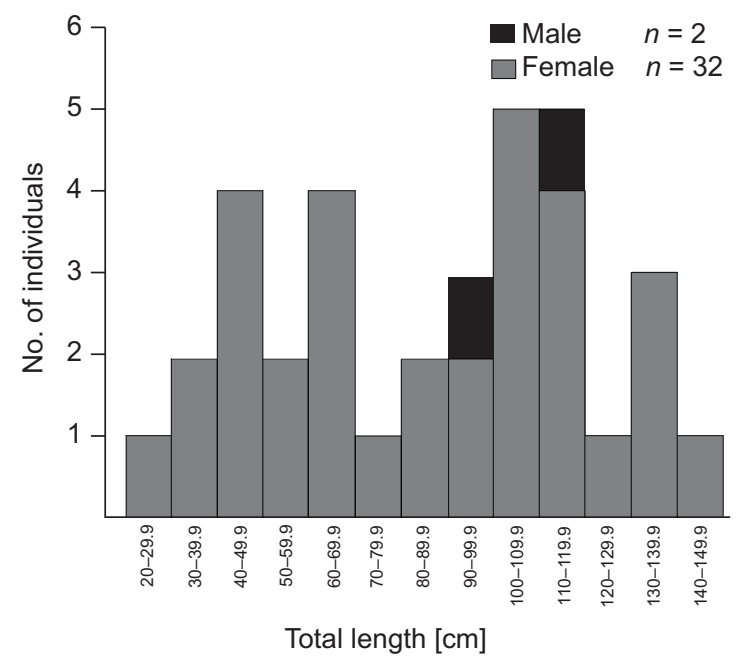

Fig. 2. Size and sex composition of Epinephelus itajara individuals in individual size groups, sampled between May 2005 and September 2010 in the Abrolhos Bank, eastern Brazil

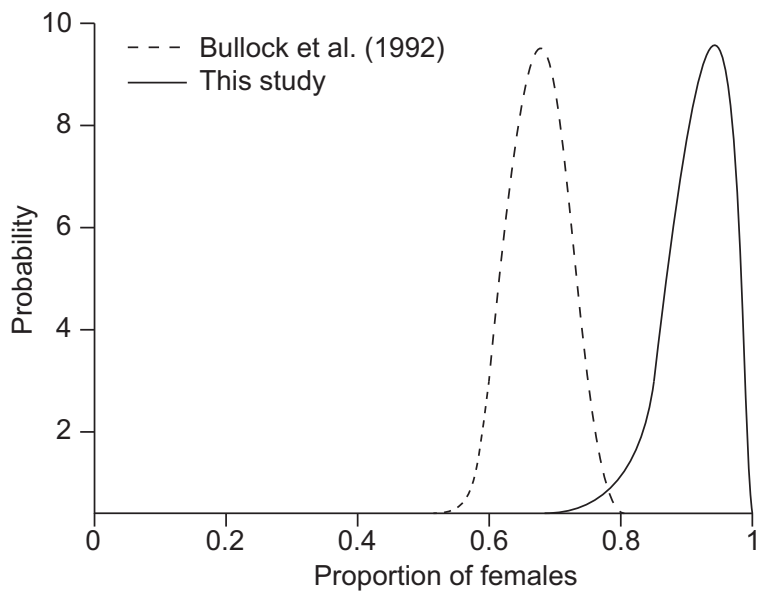

Fig. 3. Posterior distribution of the proportion of females of Epinephelus itajara from the Abrolhos Bank, eastern Brazil (south-western Atlantic population) estimated through the beta-binomial model; For comparison, the estimates of Bullock et al. (1992) obtained in the eastern Gulf of Mexico are shown 
overlap among individuals of Epinephelus itajara, NMDS analysis allowed the visualization of slightly distinct groups considering the factors studied (Fig. 7).

The SIMPER analysis performed considering juveniles and adults showed that fish remains and Acanthostracion sp. were the most important items contributing to the between-groups dissimilarities. The percentage contribution of Callinectes sp. (76.33\%) and fish remains $(22.54 \%)$ were the most important items for juveniles, while Acanthostracion sp. (100\%) was the most important items for adults. Considering habitats, SIMPER analysis showed that most of the dissimilarity betweengroups was explained by the percentage contribution of fish remains, Callinectes sp. and Cronius ruber in the diet. In mangrove samples, Callinectes sp. contributed with $83.36 \%$ and fish remains with $16.34 \%$, while in coral reef grouper, Acanthostracion sp. represented 51.01\% of food, followed by fish remains $(42.41 \%)$.

\section{DISCUSSION}

This is the first study providing basic biological information about the largest Epinephelinae species in the Atlantic Ocean. The size at first maturation of the goliath grouper in Abrolhos Bank estimated here (105.5 cm TL) was lower than that estimated by Bullock et al. (1992) in the Gulf of Mexico (males: 110 to $115 \mathrm{~cm}$ and females:
$120-135 \mathrm{~cm} \mathrm{TL})$. This suggests that the population of the Abrolhos is not recovering yet from the great fishing pressure that motivated the establishment of the fishing moratorium in 2002. According to Bullock et al. (1992) and McClenachan (2009) Epinephelus itajara is highly vulnerable to overfishing due mainly to its large size and late maturity. The size reduction at first maturity due to overfishing was reported for several other commercially important marine species (Carlson and Baremore 2003, Hutchings 2005, McBride et al. 2013). Alternative explanations for the differences between the present results and that from Bullock et al. (1992) are the relatively low sample size in the presently reported study, as well as difference between years of data collection (1980s vs. 2000s), natural variability in temperature, food availability, and predation rates. Clearly, more studies focusing on the reproduction of goliath grouper from different geographical locations are necessary to adequately address these questions.

In the Northern Hemisphere Epinephelus itajara spawns between July and September (Colin 1994, Bullock et al. 1992, Sadovy and Eklund 1999, Koenig and Coleman 2009, Mann et al. 2009). Results from this study (based solely on females) suggest that in the Abrolhos Bank the spawning season of E. itajara occurs in austral summer (January to March). Similar conclusions were

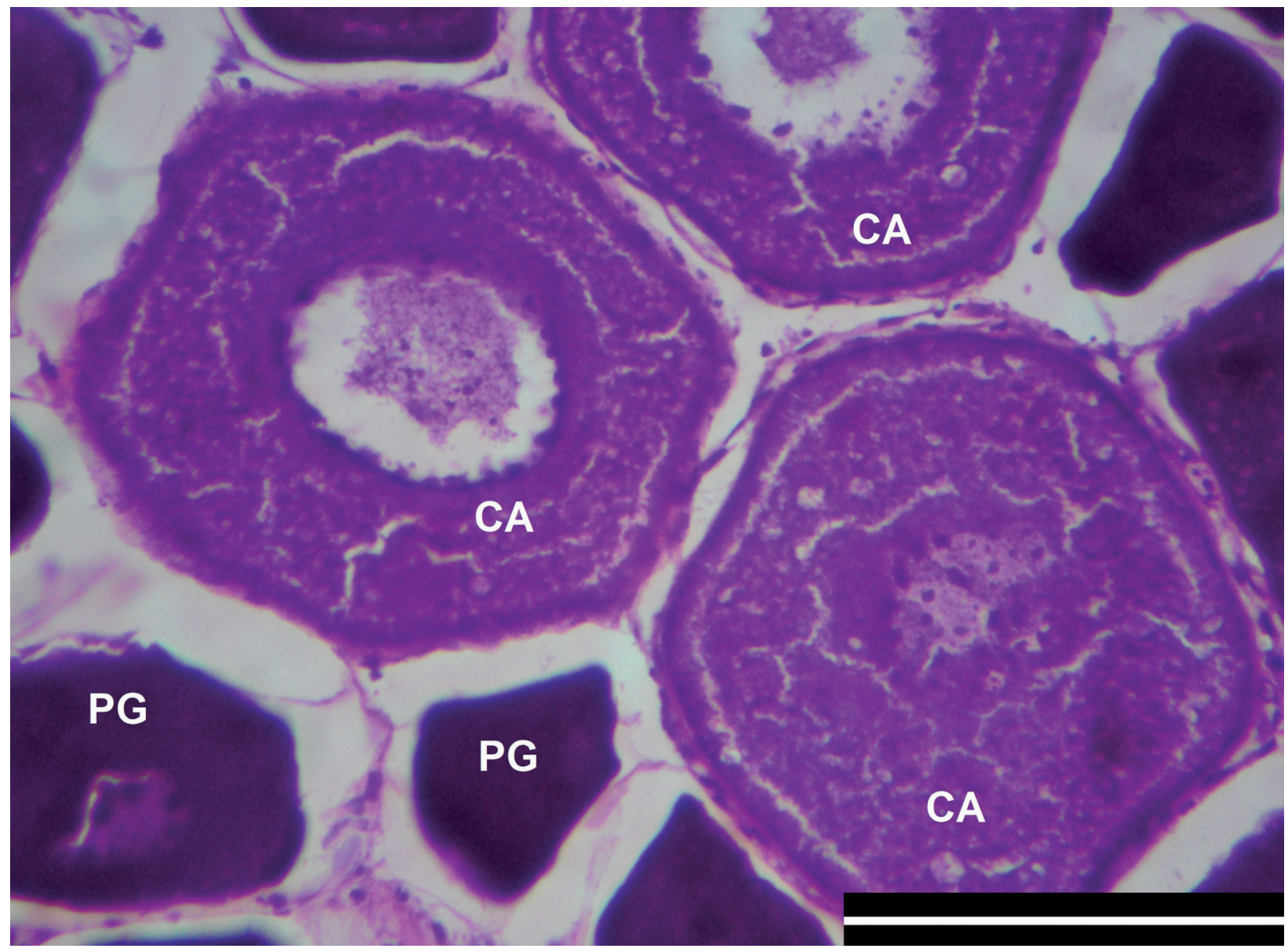

Fig. 4. Photomicrograph of ovaries of Epinephelus itajara sampled on 28 January 2007 in the Abrolhos Bank, eastern Brazil, illustrating Primary Growth (PG) and Cortical Alveolar (CA) stages; Scale bar: $10 \mu \mathrm{m}$ 
obtained to the South Atlantic in previous studies based on local ecological knowledge (Gerhardinger et al. 2006, Reuss-Strenzel and Assunção 2008) and indirect evidences (see Colin et al. 2003) such as colour patterns (Félix-Hackradt and Hackradt 2008). Although Smith (1971) assumed protogynous hermaphroditism for the goliath grouper, no conclusive evidences for this reproductive strategy were obtained here (see similar results in Bullock et al. 1992). Besides the data determined by us, the only information on sex ratios available for E. itajara was provided by Bullock et al. (1992), who estimated the sex ratio as $1.75: 1$ (females to males) in the Gulf of Mexico. For other Epinephelinae species in general the

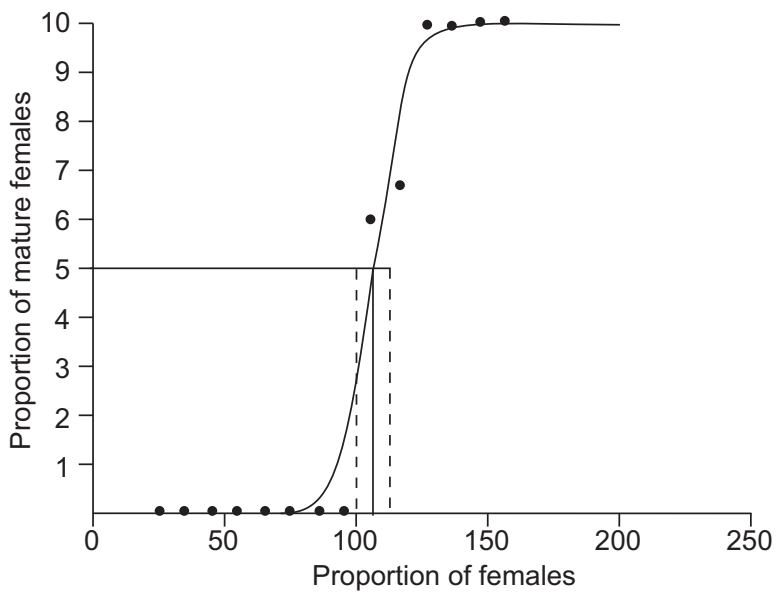

Fig. 5. Estimated logistic regression of proportion of mature females of Epinephelus itajara (maximum of the posterior distribution) in relation to total length, from the Abrolhos Bank, eastern Brazil (May 2005 to September 2007); Grey lines indicate length at which $50 \%\left(L_{50}\right)$ of individuals were mature (mean of the $L_{50}$ posterior distribution), and dashed lines indicate the $90 \%$ of credibility interval

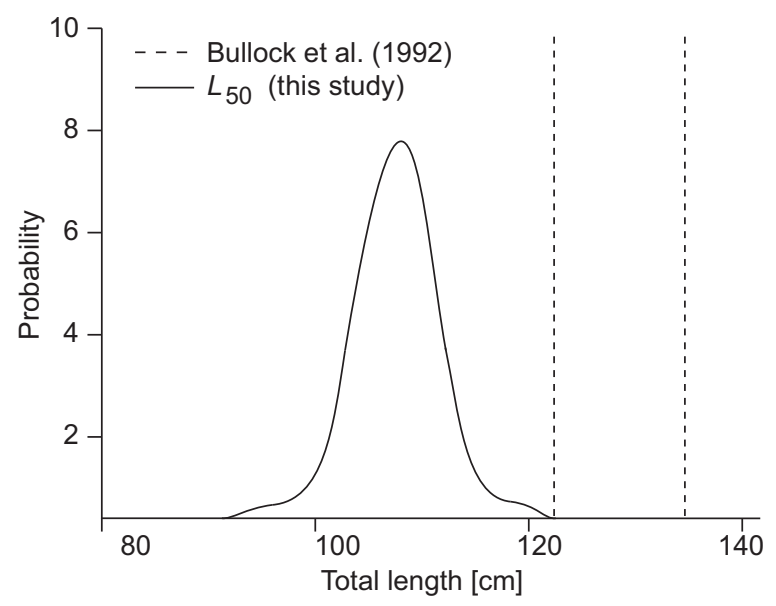

Fig. 6. Posterior distribution of the length when $50 \%$ of the females of Epinephelus itajara from the Abrolhos Bank, eastern Brazil (south-western Atlantic population) are mature $\left(\mathrm{a}=18.43, \beta=-0.017\right.$ and $L_{50}=$ 105.5); For comparison, the range of possible values for $L_{50}$ from Bullock et al. (1992) are also shown female : male proportion is around $4: 1$ (Claro et al. 1990, Brulé et al. 2003). The presently determined sex ratio is highly skewed towards females, suggesting that large males are overfished in the Abrolhos Bank. A caution is necessary, however, when comparing sex ratio estimates from different studies, because of the possible influence of gear selectivity, differences between sexes in time spent at aggregations sites, and/or migrations patterns (Sadovy and Eklund 1999).

As expected, this study supports the idea that Epinephelus itajara is a carnivorous fish (Bullock and Smith 1991, Koenig and Coleman 2009). Decapod crustaceans and fish were the most important food items observed. Similar results were obtained in previous studies. A broad array of preys is known to be consumed by E. itajara, including: Atlantic spadefish, Chaetodipterus faber (Broussonet, 1782); scrawled cowfish, Acanthostracion quadricornis (Linnaeus, 1758); striped burrfish, Chilomycterus schoepfi (Walbaum, 1792); gastropods; or decapod crustaceans (e.g., lobsters, Panulirus argus and Scyllarides sp., as well as the crabs Calappa flammea and Callinectes sp.) (see Bullock and Smith 1991, Koenig and Coleman 2009). In Brazil, Gerhardinger et al. (2006) also confirmed this pattern through surveys of fishermen ecological knowledge, which indicate that most commonly food items of the goliath grouper are lobsters, spadefish Chaetodipterus faber, octopuses, and catfish (Family Ariidae). Altogether, information on the diet of E. itajara available

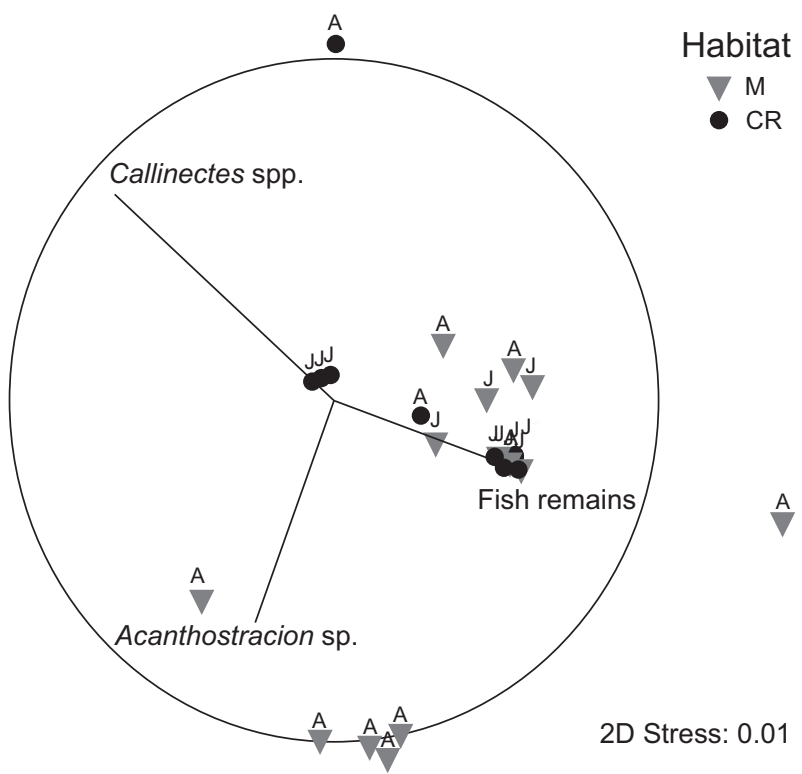

Fig. 7. Ordination plot based in the non-metric multidimensional scaling analysis (nMDS) for diets of adults (A) and juveniles (J) of Epinephelus itajara from the Abrolhos Bank, eastern Brazil using the index of relative importance (IRI) of food categories $[\log (x+1)]$. Symbols represent the factor habitat: mangrove $(\boldsymbol{\nabla})$ and coral reefs $(\bullet)$; Vectors superimposed on the nMDS diagram were created by using the Spearman's correlation on the proportionate contributions of the food categories that most influenced the ordination 
to date indicates predominance of large sized and slow moving preys (Bullock and Smith 1991). A relevant number of cowfish Acanthostracion sp. were recorded here, all from coral reef habitats. Because only dermal plates were detected, it is suggested that these structures take longer periods to be digested and are thus more frequent inside E. itajara stomachs.

Ontogenetic shifts in diet of epinephelins and lutjanids may occur when juvenile and adult fish occupy different habitats. For example, this pattern was recorded for dusky grouper, Epinephelus marginatus (Lowe, 1834) (see Machado et al. 2008); mutton snapper, Lutjanus analis (Cuvier, 1828) (see Freitas et al. 2011a); and grey snapper, Lutjanus griseus (Linnaeus, 1758) (see Randall 1967). The goliath grouper is considered a mangrovedependent species (Frias-Torres 2006), with clear ontogenetic shifts in habitat use. In general, juveniles are found in fringing mangrove shorelines, while adults occur in coral reefs, isolated patch reefs, reef/rock ledges, and artificial structures (Bohnsack and Ault 1996, Sadovy and Eklund 1999, Félix -Hackradt and Hackradt 2008). In our study, crustaceans predominated in the diet of juveniles associated with mangroves and fishes predominated in diet of adults associated with coral reefs. This variation may be due to crustaceans (the primary food item), are low in abundance in coral reef habitat and/or inaccessible to adults because of the extreme rugosity of coral reefs (Koenig and Coleman 2009, Koenig et al. 2011).

Despite of the fact that high trophic level species like adult Epinephelus itajara may cause indirect effects in the community (Heithaus et al. 2008, 2010, Ferretti et al. 2010) and influence a large range of ecological processes (Babcock et al. 1999, Pinnegar et al. 2000, Willis and Anderson 2003), the goliath grouper in the Abrolhos Bank feed primarily on prey from relatively low trophic levels (detritivorous and herbivorous), many of them with no direct economic value. In Florida (USA), population recovery of the goliath grouper did not affect the abundance of commercially important snappers and lobsters (Frias-Torres 2012). Conversely, Graham et al. (2003) observed that the reduction in groupers abundance by fishing pressure in Australia caused an increase on their small fish preys.

Alterations in large groupers populations, such as Epinephelus itajara, can have significant commercial and

Diet composition of 28 individuals of Epinephelus itajara, captured between May 2005

Table 1 and September 2010 from Abrolhos Bank

\begin{tabular}{|c|c|c|c|c|c|c|c|c|c|c|c|c|c|c|c|}
\hline \multirow{2}{*}{ Prey item } & \multicolumn{3}{|c|}{ Total } & \multicolumn{3}{|c|}{ Mangrove } & \multicolumn{3}{|c|}{ Coral reef } & \multicolumn{3}{|c|}{ Juvenile } & \multicolumn{3}{|c|}{ Adult } \\
\hline & $n$ & $F$ & IRI & $n$ & $F$ & IRI & $n$ & $F$ & IRI & $n$ & $F$ & IRI & $n$ & $F$ & IRI \\
\hline TOTAL FISH & 23 & 64.29 & 46.31 & 5 & 30.77 & 10.93 & 19 & 87.50 & 84.99 & 10 & 41.18 & 28.44 & 15 & 90.91 & 95.88 \\
\hline Fish remains & 10 & 32.14 & 28.14 & 5 & 30.77 & 10.93 & 5 & 31.25 & 29.10 & 9 & 35.29 & 27.40 & 1 & 9.09 & 1.38 \\
\hline Acantrostracion sp. & 6 & 14.29 & 12.32 & 0 & 0.00 & 0.00 & 6 & 25.00 & 37.92 & 0 & 0.00 & 0.00 & 6 & 45.45 & 70.79 \\
\hline Synodus sp. & 1 & 3.57 & 0.60 & 0 & 0.00 & 0.00 & 1 & 6.25 & 1.83 & 1 & 5.88 & 1.03 & 0 & 0.00 & 0.00 \\
\hline Diodon sp. & 2 & 3.57 & 0.60 & 0 & 0.00 & 0.00 & 2 & 6.25 & 1.86 & 0 & 0.00 & 0.00 & 2 & 9.09 & 2.93 \\
\hline Gymnothorax spp. & 1 & 3.57 & 1.30 & 0 & 0.00 & 0.00 & 1 & 6.25 & 3.95 & 0 & 0.00 & 0.00 & 1 & 9.09 & 5.64 \\
\hline Haemulon spp. & 4 & 3.57 & 1.37 & 0 & 0.00 & 0.00 & 4 & 6.25 & 4.25 & 0 & 0.00 & 0.00 & 4 & 9.09 & 6.58 \\
\hline Ocyurus chrysurus & 1 & 3.57 & 2.00 & 0 & 0.00 & 0.00 & 1 & 6.25 & 6.08 & 0 & 0.00 & 0.00 & 1 & 9.09 & 8.57 \\
\hline TOTAL DECAPODS & 24 & 71.43 & 52.77 & 14 & 61.54 & 89.07 & 10 & 37.50 & 12.12 & 18 & 66.52 & 71.20 & 6 & 45.45 & 11.56 \\
\hline Panulirus argus & 1 & 3.57 & 0.43 & 0 & 0.00 & 0.00 & 1 & 6.25 & 1.33 & 0 & 0.00 & 0.00 & 1 & 9.09 & 2.02 \\
\hline Cronius ruber & 5 & 7.14 & 3.51 & 2 & 0.00 & 0.00 & 3 & 6.25 & 3.25 & 3 & 5.88 & 1.71 & 2 & 9.09 & 3.38 \\
\hline Callinectes spp. & 13 & 25.00 & 42.59 & 11 & 53.85 & 87.97 & 2 & 6.25 & 1.63 & 11 & 41.18 & 66.51 & 0 & 0.00 & 0.00 \\
\hline C. ornatus & 1 & 25.00 & 3.41 & 1 & 7.69 & 1.10 & 0 & 6.25 & 0.00 & 0 & 0.00 & 0.00 & 1 & 9.09 & 1.26 \\
\hline Brachyura & 4 & 10.71 & 2.82 & 0 & 0.00 & 0.00 & 4 & 12.50 & 5.91 & 4 & 11.76 & 2.98 & 2 & 18.18 & 4.90 \\
\hline CORAL FRAGMENTS & 2 & 7.14 & 0.92 & 0 & 0.00 & 0.00 & 2 & 12.50 & 2.89 & 1 & 5.88 & 0.36 & 1 & 9.09 & 1.13 \\
\hline TOTAL & 51 & 142.8 & 100 & 19 & 92.3 & 100 & 32 & 137.5 & 100 & 29 & 113.57 & 100 & 22 & 145.45 & 100 \\
\hline
\end{tabular}

$n=$ number, $F=$ frequency of occurrence of the food items consumed [\%], IRI $=$ index of relative importance of individual food items $[\%]$.

Table 2

Results of two-way crossed PERMANOVA analysis on the use of food resources by Epinephelus itajara from Abrolhos Bank considering the factors of size and habitat

\begin{tabular}{lcccccc}
\hline Factor & df & SS & MS & Pseudo- $F$ & $P($ perm $)$ & UP \\
\hline Size & 1 & 8842.2 & 8842.2 & 2.44 & $0.009^{\mathrm{S}}$ & 999 \\
Habitat & 1 & 6695.5 & 6695.5 & 1.85 & 0.052 & 999 \\
Size $\times$ habitat & 1 & 7341.9 & 7341.9 & 2.03 & $0.034^{\mathrm{S}}$ & 999 \\
Residuals & 24 & 86788 & 3616.2 & & & \\
Total & 27 & $1.159 \mathrm{E} 5$ & & & & \\
\hline
\end{tabular}

$\mathrm{S}=$ significant results, $\mathrm{df}=$ degrees of freedom, $\mathrm{SS}=$ sum of squares, $\mathrm{MS}=$ mean squares, $P($ perm $)=$ permutation $P$-value, Pseudo- $F=$ PERMANOVA's statistics, UP $=$ unique values obtained under permutation. 


\section{Table 3 ACKNOWLEDGEMENTS}

Pair-wise tests based on PERMANOVA analysis considering significant factors on the use of food resources by Epinephelus itajara from Abrolhos Bank

\begin{tabular}{lcc}
\hline \multirow{2}{*}{ GRF } & \multicolumn{2}{c}{ Size $\times$ habitat } \\
\cline { 2 - 3 } & Juvenile (17) & Adult (11) \\
& M (11) vs. C (6) & M (2) vs. C (9) \\
\hline$t$ & 1.853 & 1.104 \\
$P($ perm $)$ & $0.033^{\mathrm{S}}$ & 0.426 \\
UP & 964 & 17 \\
\hline
\end{tabular}

GRF $=$ grouping factor, $\mathrm{M}=$ mangrove, $\mathrm{C}=$ coral reef, $t=$ twosample $t$-test, $P($ perm $)=$ permutation $P$-value, $\mathrm{UP}=$ unique values obtained under permutation; Number in brackets shows the number of samples, ${ }^{\mathrm{S}}$ indicates significant results.

ecological consequences (Brulé et al. 2005). Goliath grouper is dependent on the lower trophic level, and its presence, diet, and reproductive aspects could be used as indicators of the ecosystem health. The occurrence of E. itajara in the region, that comprises the largest and richest reefs in the South Atlantic (Leão and Kikuchi 2005, Moura et al. 2013), may indicate that this system still resists anthropogenic pressures, such as overfishing, pollution, and dredging (Leão and Kikuchi 2005, Moura et al. 2013).

Data presented here may help to support future conservation efforts for this threatened grouper, particularly supporting the moratorium that started in Brazil in 2002. Despite the moratorium, unfortunately, the goliath grouper is still being captured and illegally commercialized along Brazilian coast (Félix-Hackradt and Hackradt 2008, ReussStrenzel and Assunção 2008, Silva-Oliveira et al. 2008, Alarcon et al. 2009, Soares et al. 2011, Bender et al. 2013, Giglio and Freitas 2013), including mentioning in the official Brazilian fishery report, with more than $300 \mathrm{t}$ of annual illegal catches (Giglio et al. 2014). Effective protection in Florida (USA), led to the population initial recovery after 20 years, with increases in juvenile abundance (FriasTorres 2006) and return of adults to certain reef locations and spawning aggregation sites (Koenig and Coleman 2009). According to Bannerot et al. (1987) and Russ (1991) fisheries theory developed for gonochoristic populations does not apply to hermaphrodite fishes. Based on the large size of gonadal maturity observed in this study ( $>100 \mathrm{~cm}$ TL), consequently late gonadal maturity (up to 7 years), and high longevity (around 40 years) (Bullock et al. 1992), it is suggested here that the goliath grouper moratorium in Brazil should be maintained for a relatively long time frame (more than four decades). Additional measures, such as protection of key habitats such as mangroves and aggregation sites, as well as greater enforcement to avoid poaching, are urgently needed. In the absence and difficulty to collect biological data, we suggested the use of the local ecological knowledge, in conjunction with information from fisheries biology, providing essential information on biological aspects, such as spawning aggregation areas and seasonality, patterns of abundance, and feeding.
We thank Juliane Cebola, Guilherme Dutra, Danilo Araújo (CI), Beatrice Ferreira, and Sergio Rezende (UFPE), NGO Ecomar for their help in the field, advice and criticism. We thank Dr. Rosimeire Brogin for identification of several prey items and Áthila Bertoncini for helping in figures formatting. We are grateful to the Conservation International's Marine Management Areas Science Program that provided lab and logistic support. This project benefited from grants from Conservation Leadership Programme (CLP) and SISBIOTA/Rede Abrolhos (CNPq/CAPES/FAPES), as well as from a FAPESB grant to MOF and CNPq grants to RLM, CVMV and MOF (Process: 151102/2014-7). This is a contribution of the Meros do Brasil project, with financial support of the Programa Petrobras Ambiental Petrobras.

\section{REFERENCES}

Alarcon D.T., Costa R.C.D.S., Schiavetti A. 2009. Abordagem etnoecológica da pesca e captura de espécies não-alvo em Itacaré, Bahia (Brasil). [Ethnoecological approach to fishery and the bycatch of non-target species in Itacaré, Bahia (Brazil).] Boletim do Instituto de Pesca 34 (4): 675-686. [In Portuguese.]

Babcock R.C., Kelly S., Shears N.T., Walker J.W., Willis T.J. 1999. Changes in community structure in temperate marine reserves. Marine Ecology Progress Series 189: $125-134$.

DOI: $10.3354 / \mathrm{meps} 189125$

Bannerot S.P., Fox W.jr., Powers J.E. 1987. Reproductive strategies and the management of groupers and snappers in the Gulf of Mexico and Caribbean. Pp. 561-606. In: Polovina J.J., Ralston S. (eds.) Tropical snappers and groupers: biology and fisheries management. Westview Press, Boulder, CO, USA.

Bender M.G., Floeter S.R., Hanazaki N. 2013. Do traditional fishers recognize reef fish species declines? Shifting environmental baselines in Eastern Brazil. Fisheries Management and Ecology 20 (1): 58-67.

DOI: $10.1111 /$ fme.12006

Bohnsack J.A., Ault J.S. 1996. Management strategies to conserve marine biodiversity. Oceanography 9 (1): 73-82. DOI: 10.5670/oceanog.1996.30

Bowen S.H. 1996. Quantitative description of the diet. Pp. 513-532. In: Murphy B.R., Willis D.W. (eds.) Fisheries techniques. 2nd edn. American Fisheries Society, Bethesda, MD, USA.

Brown-Peterson N.J., Wyansky D.M., Saborido-Rey F., Macewicz B.J., Lowerre-Barbieri S.K. 2011. A standardized terminology for describing reproductive development in fishes. Marine and Coastal Fisheries: Dynamics, Management, and Ecosystem Science 3 (1): 52-70.

DOI: $10.1080 / 19425120.2011 .555724$

Brulé T., Puerto-Novelo E., Pérez-Díaz E., Renán-Galindo X. 2005. Diet composition of juvenile black grouper (Mycteroperca bonaci) from coastal nursery areas of the Yucatán peninsula, Mexico. Bulletin of Marine Science 77 (3): 441-452. 
Brulé T., Renan X., Colás-Marrufo T., Hauyon Y., TuzSulub A.N., Déniel C. 2003. Reproduction in the protogynous black grouper (Mycteroperca bonaci (Poey)) from the southern Gulf of Mexico. Fishery Bulletin 101 (3): 463-475.

Bullock L.H., Murphy M.D., Godcharles M.F., Mitchell M.E. 1992. Age, growth and reproduction of jewfish Epinephelus itajara in the eastern Gulf of Mexico. Fisheries Bulletin 90 (2): 243-249.

Bullock L.H., Smith G.B. 1991. Seabasses (Pisces: Serranidae). Memoirs of the Hourglass Cruises, Vol. 8, Part 2. Florida Department of Natural Resources, St. Petersburg, FL, USA.

Carlson J.K., Baremore I.E. 2003. Changes in biological parameters of Atlantic sharpnose shark Rhizoprinodon terraenovae in the Gulf of Mexico: evidence for densitydependent growth and maturity? Marine Freshwater Research 54 (3): 227-234. DOI: $10.1071 / \mathrm{MF} 02153$

Clarke K.R., Gorley R.N. 2001. PRIMER v. 5: User manual/ tutorial. PRIMER-E, Plymouth, UK.

Claro R., García-Cagide A., Sierra L.M., García-Arteaga J.P. 1990. Características biológico-pesqueras de la cherna criolla, Epinephelus striatus (Bloch) (Pisces: Serranidae) en la plataforma cubana. Ciencias Biológicas 23: 23-43.

Colin P.L. 1994. Preliminary investigations of reproductive activity of the jewfish, Epinephelus itajara (Pisces: Serranidae). Pp. 38-47. In: Proceedings of the Forty-Third Annual Gulf and Caribbean Fisheries Institute, 6 November 1990, Charleston, SC, USA.

Colin P.L., Sadovy Y., Domeier M.L. 2003. Manual for the study and conservation of reef fish spawning aggregations. Society for the Conservation of Reef Fish Aggregations, Special Publication.

Cortés E. 1999. Standardized diet compositions and trophic levels of sharks. ICES Journal of Marine Sciences 56 (5): 707-717. DOI: $10.1006 /$ jmsc. 1999.0489

Craig M.T. 2011. Epinephelus itajara. In: IUCN Red List of Threatened Species, Version 2013.1. Available from: http://www.iucnredlist.org (19 July 2013).

Craig M.T., Graham R.T., Torres R.A., Hyde J.R., Freitas M.O., Ferreira B.P., Hostim-Silva M., Gerhardinger L.C., Bertoncini A.A., Robertson D.R. 2009. How many species of goliath grouper are there? Cryptic genetic divergence in a threatened marine fish and the resurrection of a geopolitical species. Endangered Species Research 7 (3): 167-174. DOI: $10.3354 /$ esr00117

Dutra G.F., Allen G.R., Werner T., McKenna S.A. 2005. A rapid marine biodiversity assessment of the Abrolhos Bank, Bahia, Brazil. RAP Bulletin of Biological Assessment 38.

Eklund A.-M., Schull J. 2001. A stepwise approach to investigate the movement patterns and habitat utilization of goliath grouper, Epinephelus itajara, using conventional tagging, acoustic telemetry and satellite tracking. Pp. 189-216. In: Sibert J.R., Nielsen J.L. (eds.) Electronic tagging and tracking in marine fisheries. Kluwer Academic Publishers, Amsterdam, the Netherlands.

Farmer B.M., Wilson S.K. 2011. Diet of finfish targeted by fishers in North West Australia and the implications for trophic cascades. Environmental Biology of Fishes 91 (1): 71-85.

DOI: $10.1007 / \mathrm{s} 10641-010-9761-3$

Félix-Hackradt F.C., Hackradt C.W. 2008. Populational study and monitoring of the goliath grouper, Epinephelus itajara (Lichtenstein, 1822), in the coast of Paraná, Brazil. Natureza e Conservação 6 (2): 141-156.

Ferreira B.P., Maida M. 1995. Projeto Mero: apresentação e resultados preliminares. [Mero project: presentation and preliminary results.] Boletim Técnico Cientifico do CEPENE 3 (1): 201-210. [In Portuguese.]

Ferretti F., Worm B., Britten G.L., Heithaus M.R., Lotze H.K. 2010. Patterns and ecosystem consequences of shark declines in the ocean. Ecology Letters 13 (8): 1055-1071. DOI: $10.1111 / j .1461-0248.2010 .01489 . x$

Fournier D.A., Skaug H.J., Ancheta J., Ianelli J., Magnusson A., Maunder M.N., Nielsen A., Sibert J. 2012. AD Model Builder: using automatic differentiation for statistical inference of highly parameterized complex nonlinear models. Optimization Methods and Software 27 (2): 233-249. DOI: $10.1080 / 10556788.2011 .597854$

Francini-Filho R.B., Coni E.O.C., Meirelles P.M., AmadoFilho G.M., Thompson F.L., Pereira-Filho G.H., Bastos A.C., Abrantes D.P., Ferreira C.M., Gibran F.Z., Güth A.Z., Sumida P.Y.G., Oliveira N.L., Kaufman L., Minte-Vera C.V., Moura R.L. 2013. Dynamics of coral reef benthic assemblages of the Abrolhos Bank, eastern Brazil: Inferences on natural and anthropogenic drivers. Plos One 8: e54260.

DOI: 10.1371/journal.pone.0054260

Francini-Filho R.B., de Moura R.L. 2008a. Dynamics of fish assemblages on coral reefs subjected to different management regimes in the Abrolhos Bank, eastern Brazil. Aquatic Conservation: Marine and Freshwater Ecosystems 18 (7): 1166-1179.

DOI: 10.1002 aqc.966

Francini-Filho R.B., Moura R.L. 2008b. Evidence for spillover of reef fishes from a no-take marine reserve: An evaluation using the before-after control-impact (BACI) approach. Fisheries Research 93 (3): 346-356.

DOI: 10.1016/j.fishres.2008.06.011

Freitas M.O., Abilhoa V., da Costa e Silva G.H. 2011a. Feeding ecology of Lutjanus analis (Teleostei: Lutjanidae) from Abrolhos Bank, Eastern Brazil. Neotropical Ichthyology 9 (2): 411-418.

DOI: $10.1590 / \mathrm{S} 1679-62252011005000022$

Freitas M.O., de Moura R.L., Francini-Filho R.B., MinteVera C.V. 2011b. Spawning patterns of commercially important reef fish (Lutjanidae and Serranidae) in the tropical western South Atlantic. Scientia Marina 75 (1): 134-146. DOI: $10.3989 /$ scimar.2011.75n1135

Freitas M.O., Rocha G.R.A, Chaves P.T.C., De Moura R.L. 2014. Reproductive biology of the lane snapper, Lutjanus synagris, and recommendations for its management on the Abrolhos Shelf, Brazil. Journal of the Marine Biological Association of the United Kingdom 94 (8): 1711-1720. DOI: $10.1017 / \mathrm{S} 0025315414001088$

Frias-Torres S. 2006. Habitat use of juvenile goliath grouper Epinephelus itajara in the Florida Keys, USA. Endangered Species Research 2: 1-6. DOI: $10.3354 /$ esr002001 
Frias-Torres S. 2012. Should the critically endangered goliath grouper Epinephelus itajara be culled in Florida? Oryx 47 (1): 88-95. DOI: $10.1017 / \mathrm{S} 0030605312000361$

Frias-Torres S., Barroso P., Eklund A.M., Schull J., Serafy J. 2007. Activity patterns of three juvenile goliath grouper, Epinephelus itajara, in a mangrove nursery. Bulletin of Marine Sciences 80 (3): 587-594.

Frias-Torres S., Luo J. 2009. Using dual-frequency sonar to detect juvenile goliath grouper Epinephelus itajara in mangrove habitat. Endangered Species Research 7: 237-242. DOI: $10.3354 /$ esr00138

Gelman A., Carlin J.B., Stern H.S., Rubin D.B. 2004. Bayesian data analysis. 2nd edn. Chapman and Hall/CRC Texts in Statistical Science.

Gerhardinger L.C., Hostim-Silva M., Medeiros R.P., Matarezi J, Bertoncini A.A., Freitas M.O., Ferrreira B.P. 2009. Fisher's resource mapping and goliath grouper Epinephelus itajara (Serranidae) conservation in Brazil. Neotropical Ichthyology 7 (1): 93-102. DOI: $10.1590 /$ S1679-62252009000100012

Gerhardinger L.C., Medeiros R., Marenzi R.C., Bertoncini A.A., Hostim-Silva M. 2006. Local ecological knowledge on the goliath grouper Epinephelus itajara (Teleostei: Serranidae) in Southern Brazil. Neotropical Ichthyology 4 (4): 441-450. DOI: $10.1590 / \mathrm{S} 1679-62252006000400008$

Giglio V.J., Bertoncini A.A., Ferreira B.P., Hostim-Silva M., Freitas M.O. 2014. Landings of goliath grouper, Epinephelus itajara, in Brazil: despite prohibited over ten years, fishing continues. Natureza e Conservação 12 (2): 118-123.

DOI: 10.1016/j.ncon.2014.09.004

Giglio V.J., Freitas M.O. 2013. Caracterização da pesca artesanal com rede de camboa praticada na Reserva Extrativista do Cassurubá, Bahia. [Characterization of artisanal fishery with camboa net at the Cassurubá Extractive Reserve, Bahia.] Biotemas 26 (2): 249-259. [In Portuguese.] DOI: $10.5007 / 2175-7925.2013 v 26 n 2 p 249$

Graham N.A.J., Evans R.D., Russ G.R. 2003. The effects of marine reserve protection on the trophic relationships of reef fishes on the Great Barrier Reef. Environmental Conservation 30 (2): 200-208.

DOI: $10.1017 / \mathrm{S} 0376892903000195$

Heemstra P.C., Randall J.E. 1993. FAO species catalogue: Groupers of the world (Family Serranidae, subfamily Epinephelinae). An annotated and illustrated catalogue of the grouper, rockcod, hind, coral grouper and lyretail species known to date. FAO Fisheries Synopsis 16 (125): 1-382.

Heithaus M.R., Frid A., Vaudo J.J., Worm B., Wirsing A.J. 2010. Unraveling the ecological importance of elasmobranchs. Pp. 611-637. In: Carrier J.C., Musick J.A., Heithaus M.R. (eds.). Sharks and their relatives II: Biodiversity, adaptive physiology and conservation. CRC Press, Boca Raton, FL, USA.

Heithaus M.R., Frid A., Wirsing A.J., Worm B. 2008. Predicting ecological consequences of marine top predator declines. Trends in Ecology and Evolution 23 (4): 202-210. DOI: 10.1016/j.tree.2008.01.003

Hostim-Silva M., Bertoncini A.A., Gerhardinger L.C., Machado L.F. 2005. The "Lord of the Rock's" conserva- tion program in Brazil: the need for a new perception of marine fishes. Coral Reefs 24 (1): 74.

DOI: $10.1007 / \mathrm{s} 00338-004-0437-3$

Hutchings J.A. 2005. Life history consequences of overexploitation to population recovery in Northwest Atlantic cod (Gadus morhua). Canadian Journal of Fisheries and Aquatic Sciences 62 (4): 824-832.

DOI: 10.1139/F05-081

Hyslop E.J. 1980. Stomach contents analysis - a review of methods and their application. Journal of Fish Biology 17 (4): 411-429. DOI: $10.1111 / j .1095-8649.1980 . t b 02775 . x$

Kinas P.G., Andrade H.A. 2010. Introdução à análise Bayesiana (com R). [Introduction to Bayesian analysis (R).] MaisQnada, Porto Alegre, Brazil.

King M. 2007. Fisheries biology, assessment and management. 2nd edn. Blackwell Publishing Oxford, UK.

Koenig C.C., Coleman F.C. 2009. Population density, demographics, and predation effects of adult goliath grouper. National Oceanic and Atmospheric Administration, MARFIN Project Final Report.

Koenig C.C., Coleman F.C., Kingon K. 2011. Pattern of recovery of the goliath grouper Epinephelus itajara population in the southeastern US. Bulletin of Marine Science. 87 (4): 891-911. DOI: $10.5343 / \mathrm{bms} .2010 .1056$

Leão Z.M.A.N., Kikuchi R.K.P. 2005. A relic coral fauna threatened by global changes and human activities, Eastern Brazil. Marine Pollution Bulletin 51 (5-7): 599-611. DOI: 10.1016/j.marpolbul.2005.04.024

Machado L.F., Daros F.A.M.L, Bertoncini A.A., HostimSilva M., Barreiros J.P. 2008. Feeding strategy and trophic ontogeny in Epinephelus marginatus (Serranidae) from southern Brazil. Cybium 32 (1): 33-41.

Mann D.A., Locascio J.V., Coleman F.C., Koenig C.C. 2009. Goliath grouper Epinephelus itajara sound production and movement patterns on aggregation sites. Endangered Species Research 7 (3): 229-236.

DOI: $10.3354 /$ esr00109

Matsuura K. 2001. Ostraciidae. Boxfishes. Pp. 3948-3951. In: Carpenter K.E., Niem V. (eds.) FAO species identification guide for fishery purposes. The living marine resources of the Western Central Pacific, Vol. 6, FAO, Rome, Italy.

McBride R.S., Vidal T.E., Cadrin S.X. 2013. Changes in size and age at maturity of the northern stock of tilefish (Lopholatilus chamaeleonticeps) after a period of overfishing. Fishery Bulletin 111 (2): 161-174.

DOI: $10.7755 /$ FB.111.2.4

McClenachan L. 2009. Historical declines of goliath grouper populations in South Florida, USA. Endangered Species Research 7 (3): 175-181.

DOI: $10.3354 /$ esr00167

Morris A.V., Roberts C.M., Hawkins J.P. 2000. The threatened status of groupers (Epinephelinae). Biodiversity Conservation 9 (7): 919-942.

DOI: 10.1023/A:1008996002822

Moura R.L., Francini-Filho R.B., Chaves E.M., Minte-Vera C.V., Lindeman K.C. 2011. Use of riverine through reef habitat systems by dog snapper (Lutjanus jocu) in eastern Brazil. Estuarine and Coastal Shelf Science 95 (1): 274-278. DOI: $10.1016 /$ j.ecss.2011.08.010 
Moura R.L., Secchin N.A., Amado-Filho G.M., FranciniFilho R.B., Freitas M.O., Minte-Vera C.V., Teixeira J.B, Thompson F.L., Dutra G.F., Sumida P.Y.G, Guth A.Z., Lopes R.M., Bastos A.C. 2013. Spatial patterns of benthic megahabitats and conservation planning in the Abrolhos Bank. Continental Shelf Research 70: 109-117. DOI: 10.1016/j.csr.2013.04.036

Pauly D., Christensen V., Dalsgaard J., Froese R., Torres F.jr. 1998. Fishing down marine food webs. Science 279 (5352): 860. DOI: $10.1126 /$ science. 279.5352 .860

Pilling G.M., Apostolaki P., Failler P., Floros C., Large P.A., Morales-Nin B., Reglero P., Stergiou K.I., Tsikliras A.C. 2008. Assessment and management of data-poor fisheries. Pp. 280-305. In: Payne A., Cotter J., Potter T. (eds.) Advances in fisheries science: 50 years on from Beverton and Holt. Blackwell Publishing, Oxford, UK.

Pinkas L., Oliphant M.S., Iverson I.L.R. 1971. Food habits of albacore, bluefin tuna, and bonito in California waters. Fish Bulletin 152: 1-105.

Pinnegar J.K., Polunin N.V.C., Francour P., Badalamenti F., Chemello R., Harmelin-Vivien M.-L., Hereu B., Milazzo M., Zabala M., D’Anna G., Pipitone C. 2000. Trophic cascades in benthic marine ecosystems: lessons for fisheries and protected-area management. Environmental Conservation 27 (2): 179-200.

Previero M., Minte-Vera C.V., de Moura R.L. 2013. Fisheries monitoring in Babel: fish ethnotaxonomy in a hotspot of common names. Neotropical Ichthyology 11 (2): 467-476. DOI: $10.1590 /$ S1679-62252013000200016

Randall J.E. 1967. Food habits of reef fishes of the West Indies. Studies in Tropical Oceanography 5: 665-847.

Reuss-Strenzel G.M., Assunção M.F. 2008. Etnoconhecimento ecológico dos caçadores submarinos de Ilhéus, Bahia, como subsídio à preservação do mero (Epinephelus itajara Lichtenstein, 1822). [Ecological ethnoknowledge of the underwater fishermen of Ilhéus, Bahia, in support of the conservation of the goliath grouper (Epinephelus itajara Lichtenstein, 1822).] Revista da Gestão Costeira Integrada 8 (2): 203-219. DOI: 10.5894/rgci137 [In Portuguese.]
Russ G.R. 1991. Coral reef fisheries: effects and yields. Pp. 601-635. In: Sale P.F. (ed.) The ecology of fishes on coral reefs. Academic Press, San Diego, CA, USA.

Sadovy Y., Eklund A. 1999. Synopsis of biological data on the Nassau grouper, Ephinephelus striatus, and the Jewfish, E. itajara (Lichtenstein, 1822). NOAA Technical Report NMFS 146: A Technical Report of the Fishery Bulletin FAO Fisheries Synopsis 157.

Silva-Oliveira G.C., Rêgo P.S., Schneider H., Sampaio I., Vallinoto M. 2008. Genetic characterization of populations of the critically endangered goliath grouper (Epinephelus itajara, Serranidae) from the northern Brazilian coast through analyses of mtDNA. Genetics and Molecular Biology 31 (4): 988-994.

DOI: $10.1590 / \mathrm{S} 1415-47572008005000016$

Silva-Oliveira G.C., Silva A.B.C., Oliveira Y., Nunes Z.P., Torres R.A., Sampaio I., Vallinoto M. 2013. New nuclear primers for molecular studies of Epinephelidae fishes. Conservation Genetic Resources 5 (1): 165-168. DOI: $10.1007 / \mathrm{s} 12686-012-9759-6$

Smith C.L. 1971. A revision of the American groupers: Epinephelus and allied genera. Bulletin of American Museum of Natural History 146: 69-241.

Soares L.S.H., Lopez J.P., Muto E.Y., Giannini R. 2011. Capture fishery in northern Todos os Santos Bay, tropical southwestern Atlantic, Brazil. Brazilian Journal of Oceanography 59 (1): 61-74. DOI: $10.1590 / \mathrm{S} 1679-87592011000100005$

Willis T.J., Anderson M.J. 2003. Structure of cryptic reef fish assemblages: relationships with habitat characteristics and predator density. Marine Ecology Progress Series 257: 209-221.

DOI: $10.3354 / \mathrm{meps} 257209$

Received: 3 April 2014 Accepted: 29 September 2014 Published electronically: 31 March 2015 